УДК 349.22

\author{
Г. I. Чанишева, P. I. Чанишев
}

\title{
ПОНЯТТЯ, ВИДИ ТА ЮРИДИЧНА ПРИРОДА ПРАВА НА ІНФОРМАЦІЮ СТОРІН ТРУДОВОГО ДОГОВОРУ
}

Відповідно до чинного трудового законодавства працівники, роботодавці та їх представники наділені інформаційними правами й обов'язками. Ідеться, зокрема, про право працівника на отримання від роботодавця повної й достовірної інформації про умови праці, охорону праці, якому кореспондує відповідний обов'язок роботодавця, у тому числі обов'язок інформувати про умови праші, закріплені в локальних нормативно-правових актах.

За відсутності спеціальної норми, згідно із чинним законодавством, право працівників на інформацію про умови праці постає зі змісту ст. 29 Кодексу законів про працю України (далі - КЗпП України), яка встановлює обов'язок власника або уповноваженого ним органу проінструктувати працівника й визначити його робоче місце. Стаття 29 зобов'язує власника або уповноважений орган до початку роботи за укладеним трудовим договором проінформувати під розписку про умови праці, наявність на робочому місші, де він буде прашювати, небезпечних $і$ шкілливих виробничих факторів, які ше не усунуто, та можливі наслідки їх впливу на здоров'я, його права на пільги й компенсації за роботу в таких умовах відповідно до чинного законодавства й колективного договору. Однак у назві статті про зазначений обов'язок власника не згадується. Аналогічний обов'язок під час укладення трудового договору покладено на роботодавця ч. 2 ст. 5 Закону України «Про охорону праці».

Наявність цих та інших правових норм, шо закріплюють право працівника й роботодавця як сторін трудового договору на отримання певної інформашії, пов'язаної з виконанням трудових обов'язків, обумовлюе необхідність розробки теоретичних засад реалізації зазначеного права в межах трудових правовідносин.

Тривалий час право на інформацію досліджувалося виключно представниками науки конституційного права. Нині різні аспекти реалізації зазначеного права розглядаються в роботах вітчизняних і зарубіжних учених, зокрема представників конституційного, інформаційного, адміністратив- 
ного, міжнародного, кримінального й інших галузей права: I.В. Арістової, В.М. Баранова, І.Л. Бачило, В.М. Брижка, В.Д. Гавловського, А.М. Колодія, Б.А. Кормича, В.В. Копейчикова, В.А. Ліпкана, О.В. Логінова, А.І. Марушака, Ф.М. Рудинського, Ю.Н. Тодики та ін. До дослідження права на інформацію як суб 'єктивного трудового права звернулися також представники науки трудового права: А.М. Лушнікова, М.В. Лушнікова, I.В. Вєтухова та ін. Проб.темі розробки ефективного галузевого механізму забезпечення права на інформацію працівників і роботодавців та їх представників було присвячено кандидатську дисертацію Р.I. Чанишева [1].

Метою статті $€$ визначення поняття, видів і юридичної природи права на інформацію сторін трудового договору.

У загальній теорії права суб'єктивне право визначається як передбачена для правомочної особи в шілях задоволення ії інтересів міра можливої поведінки, забезпечена юридичними обов'язками інших осіб [2, с. 352]. Ознаками цього права називаються такі:

1) суб'єктивне право є мірою можливої поведінки. Щодо суб'єктивного права міра включає вид і розмір можливої поведінки;

2) зміст суб'єктивного права встановлюється нормами права та юридичними фактами;

3) здійснення суб'єктивного права забезпечено обов'язком іншої сторони. В одних випадках цей обов'язок полягає в утриманні від дій, що порушують суб'єктивне право іншої сторони, в інших випадках це право забезпечується виконанням обов'язку, тобто активними діями зобов'язаної особи;

4) суб'єктивне право надається правомочній особі для задоволення іï інтересів; за відсутністю останнього стимул для здійснення суб'єктивного права втрачається;

5) це право полягає не тільки в можливості, а й у юридичній або фактичній поведінці правомочної особи.

При цьому суб'єктивне право розглядається як складне явише, що включає низку правомочностей:

- право на власні фактичні діï, спрямовані на використання корисних властивостей об'єкта права;

- право на юридичні діï, на прийняття юридичних рішень;

- право вимагати від іншої сторони виконання обов'язку, тобто право на чужі діiі;

- право домагання, яке полягає в можливості привести в дію апарат примусу проти зобов'язаної особи, тобто право на примусове виконання обов'язку [2, с. 353].

П.Р. Рабінович визначає суб’єктивне право особи як закріплену в юридичних нормах можливість іiі певної поведінки, спрямованої на здійснення відповідних прав людини [3, с. 79].

У теорії інформаційного права суб'єктивне право на інформацію визначається як гарантована державою можливіссть фізичних, юридичних осіб i держави (державних органів) ві.льно одержувати, використовувати, по- 
ширювати та зберігати відомості, необхідні їм для реалізації своїх прав, свобод і законних інтересів, здійснення завдань і функцій, шо не порушує права, своболи й законні інтереси інших громадян, права й інтереси юридичних осіб [4, с. 43].

Право на інформацію, згідно з трудовим законодавством, як суб'єктивне трудове право можна визначити як гарантовану державою можливість вільного одержання, використання, поширення, зберігання та захисту інформації, необхідної суб'єктам трудових правовідносин для реалізації індивідуальних і колективних трудових прав, свобод і законних інтересів.

В інформаційному праві право на інформацію підлягає класифікації за різними підставами. Так, одним із критеріїв називається зв'язок права на інформацію із предметом правового регулювання різних галузей права. За шим критерієм виділяються права на інформацію, які пов'язані з предметом правового регулювання конституційного (право на інформацію про діяльність органів державної влади), цивільного (право власності на інформацію), сімейного (право на інформацію про стан здоров'я заручених), господарського (право суб'єкта господарювання на одержання інформації про результати перевірок його діяльності), фінансового (право на інформацію про державний бюджет) та інших галузей права.

Використовуючи критерії класифікації, що застосовуються в теорії інформаційного права, можна виділити такі види права на інформацію за трудовим законодавством. За типом інформації розрізняються право на документовану інформацію та право на публічно оголошену інформацію.

За суб'єктами розрізняються право на інформацію працівників, право на інформацію роботодавців і право на інформацію представників працівників і роботодавців.

За режимом доступу виділяють право на відкриту інформацію та право на інформацію з обмеженим доступом.

За способом правового регулювання виділяються права на інформацію, механізм реалізації яких закріплений імперативним способом (право на інформацію $з$ об́меженим доступом) чи частково регламентований (право на масову інформацію).

За ознаками діяльності (існування) суб'єкта розрізняються пасивне право на інформашію (пов'язане з існуванням суб' $є$ кта, наприклад право на інформацію про стан здоров'я працівника) та активне право на інформацію (пов'язане з діяльністю роботодавця, наприклад право на інформацію, що становить комерційну таємницю).

Право на інформацію працівників і роботодавців і ї представників як суб'єктивне трудове право має свої юридичні характеристики. У теоріі права набула поширення концепція регулятивних та охоронних суб'єктивних прав у зв'язку із широким визнанням розмежування регулятивних та охоронних правовідносин, а також принципово іншим трактуванням права на захист [5]. У зв'язку із шим виділяють регулятивні суб'єктивні права, що існують у межах регулятивних правовідносин, та охоронні суб'єктивні права (право на захист). У свою чергу регулятивні суб'єк- 
тивні трудові права можна поділити на дві основні групи. Першу групу складають права, пов'язані з власне однобічними діями правомочної особи (наприклад, право роботодавця розірвати трудовий договір за підставами, передбаченими законом, право роботодавця заохотити працівника). Друга група регулятивних суб'єктивних трудових прав передбачає право вимагати певної поведінки від зобов'язаної особи (наприклад, право працівника на надання роботи, передбаченої трудовим договором, право на своєчасну й повну виплату заробітної плати тощо). Отже, суб'єктивне регулятивне трудове право може включати як право на свої діï, так і право на чужі діï (право-домагання).

Охоронне суб'єктивне право - це право на захист. Воно реалізується в межах особливих охоронних правовідносин, які у свою чергу поділяються на матеріальні та процесуальні. Суб'єктивне право на захист у матеріальних охоронних правовідносинах реалізується зусиллями правомочної особи, чиї права порушено, не звертаючись до юрисдикційних органів. Право на захист у процесуальному значенні означає можливість особи звернутися за захистом свої прав (порушенні або освоювані) до юрисдикційних органів.

Право на інформацію сторін трудового договору відноситься до другої групи регулятивних суб'єктивних трудових прав, оскільки включає як право на свої дії, так і право на чужі дії (право-домагання).

Право на інформацію належить до основних трудових прав, передбачених міжнародними актами. У сучасній науці трудового права основні трудові права досліджуються В.М. Андріївим [6], Є.В. Красновим [7]. Здійснюючи класифікацію основних трудових прав за різними підставами, Є.В. Краснов за способом формулювання вирізняє основні трудові права, які сформульовані як рекомендаційні, оціночні базові поняття, і права, пов'язані з певними матеріальними (нематеріальними) благами. Право на інформацію належить до основних трудових прав, пов'язаних із забезпеченням нематеріального інтересу.

За суб'єктною ознакою й залтежно від порядку реалізації трудові права поділяються на індивідуальні та колективні. Як відзначає В.М. Андріїв, систему трудових прав прашівників утворюють індивідуальні та колективні трудові права, частина з яких належить до основних трудових прав [6, с. 26].

У вітчизняній науці трудового права колективні трудові права вперше було досліджено в докторській дисертації одного з авторів цієї статті [8]. У дисертації колективні трудові відносини як складова предмета трудового права визначено як суспільні відносини, що виникають у процесі реалізації працівниками й роботодавцями та їхніми представниками колективних трудових прав відповідно до чинного законодавства. Звертається увага на те, шо створення дійового юридичного механізму забезпечення (реалізашії, охорони й захисту) зазначених прав є одним із перспективних напрямів розвитку сучасного трудового права $[8$, с. 29].

У міжнародних актах про права людини проголошено такі колективні трудові права, як право працівників і роботодавців на свободу об'єднання, 
право працівників на участь в управлінні організацією, право працівників i роб́тодавців на колективні переговори, право працівників і робоотодавців на укладання колективних договорів, право працівників на інформацію й консультації, право працівників і роботодавців на вирішення колективних трудових спорів (Європейською соніальною хартією (переглянутою) передбачено право працівників і роботодавців на колективні дії, включаючи право на страйк), право працівників отримувати інформацію й консультації під час колективного звільнення.

Зазначені права $є$ колективними не тільки через те, що реалізуються колективними суб'єктами (організаціями роботодавців (іх об'єднаннями), колективами працівників, профспілками (іх об'єднаннями), первинними профспілковими організашіями та іх виборними органами, примирно-посередницькими органами з вирішення колективних трудових спорів та ін.). Колективний характер цих прав обумовлений також формою (порядком) ix реалізації як безпосередньо колективом працівників, так і через уповноважених представників. Водночас такі трудові права, як право на працю, право на належні, безпечні та здорові умови праці, право на відпочинок тощо, залежно від суб'єктної ознаки й порядку реалізації $є$ за своєю природою індивідуальними трудовими правами.

Право на інформацію, згідно з трудовим законодавством, відноситься як до індивідуальних, так і колективних трудових прав. Право на інформацію як індивідуальне трудове право здійснюється працівником і роботодавцем особисто, $\epsilon$ невідчужуваним, не може бути передане іншим особам. Натомість право на інформацію як колективне трудове право через його юридичну природу здійснюється як безпосередньо працівниками (трудовим колективом), так і через представників працівників і роботодавців.

Право на інформацію варто віднести також до особистих немайнових трудових прав, шо утворюють особливу групу трудових прав, у змісті яких основною є особистісна складова.

У 60-ті pр. у науці трудового права до аналізу особистих немайнових прав звернувся М.I. Бару, який здійснив комплексне дослідження права на трудову честь [9]. Розглядаючи майновий та особистісний елементи в сопіалістичному трудовому правовідношенні, Л.Я. Гінцбург відніс до його змісту майнові й особисті немайнові права $[10$, с. 71-85].

Трудові права класифікуються залежно від матеріального інтересу на трудові права, реалізація яких забезпегує матеріальний інтерес, і права, пов'язані із забезпеченням нематеріального інтересу (особисті немайнові трудові права). Дослідження останніх у межах трудоправової проблематики видається актуальним і своєчасним.

Загальновизнано, шо в предметі трудового права органічно поєднуються особистісні, організаційні й майнові відносини. На думку Р.З. Лівшиця, усі галузі права (крім державного і конститушійного) пов'язані тільки 3 трьома групами відносин: майновими, особистими й організаційними. Через об'єктивні причини найбільш докладно ці групи відносин, у тому числі особисті немайнові, досліджено фахівцями із цивільного права. У Цивіль- 
ному кодексі України право на інформацію фізичної особи закріплюється як особисте немайнове право.

Постановка проблеми про особисті немайнові трудові права видається актуальною, оскільки такий підхід дозволить більш грунтовно дослідити юридичну природу особливої групи трудових прав, у змісті яких основною $\epsilon$ особистісна складова. Ідеться про такі трудові права: право на рівне поводження й захист від дискримінації в трудових відносинах, право на захист персональних даних і недоторканість особистого життя в трудових відносинах, право на захист честі, гідності й ділової репутації в період трудової діяльності. До таких прав належить також право працівників на повну й достовірну інформацію в трудових відносинах. Дослідження особистих немайнових трудових прав дозволить також більш чітко розмежувати предмети трудового й циві.тьного права, визначити ї точки дотику.

Ідея особистих трудових прав працівника підтримується в сучасній літературі. Як відзнатають Є.Б. Хохлов і В.А. Сафонов, особисті права працівника нематеріального характеру мають не менш суттєве значення, ніж права, що мають у той чи іншій формі матеріальне вираження (наприклад, право на справедливі та сприятливі умови праці). До особистих прав учені відносять передусім такі: а) право на захист гідності працівника в період трудової діяльності; б) право на недоторканість особистого життя (це право розглядається через категорію «захист персональних даних працівника») $[11$, с. $136-137]$.

Грунтовне дослідження особистих немайнових трудових прав здійснено вітчизняною дослідницею І.В. Лагутіною [12], метою докторської дисертації якої $є$ розвиток теорії трудового права щодо юридичної природи особистих немайнових трудових прав і галузевого механізму їх забезпечення, внесення теоретично обгрунтованих пропозицій щодо вдосконалення чинного законодавства, проекту Трудового кодексу України в цій сфері. Предметом дослідження вченого стали такі особисті немайнові трудові права, як право на здорові й безпечні умови праці, право на трудову честь i гідність, право на професійне навчання, право на рівноправність і недопушення дискримінації, право на захист персональних даних працівників.

Особисті немайнові трудові права працівника у своїй основі мають особистісну домінанту, яскраво виражений характер нематеріальних благ людини, які захищаються законом. Спільними ознаками об'єкта особистих немайнових трудових прав та особистих немайнових цивільних прав $€$ те, що, як відзначає M.M. Малеїна, на нематеріальні блага не поширюються показники ваги, розміру, об'єму, характерні для речей, стандарти якості й технічні регламенти, що застосовуються для робіт і послуг, не використовуються умови патентоспроможності, передбачені для кваліфікації винаходів, корисних моделей, промислових зразків. Таким чином, нематеріальна блага не мають стандартних параметрів (показників) [13, с. 41]. Можна виділити нематеріальні блага, які $€$ одночасно об'єктом особистих немайнових трудових прав та особистих немайнових прав, що охороняються сучасним цивільним законодавством. Ідеться про такі нематеріальні блага, 
як життя, здоров'я, честь, ділова репутація, гідність, таємниця й недоторканність приватного життя. Специфікою ших та інших нематеріальних благ $\epsilon$ невідчужуваність і непередаваність. Реалізація особистих немайнових трудових прав, як і особистих немайнових шивільних прав, спрямована на виявлення, розвиток та/або збереження індивідуальності особистості.

Проте особисті немайнові трудові права мають істотні відмінності від особистих немайнових прав, які не пов'язані з майновими та які охороняються циві.льним законодавством. До особливостей особистих немайнових трудових прав працівника варто віднести такі. Носіями зазначених прав можуть бути тільки працівники, а носіями права на працю - тільки фізичні особи, які мають трудову правосуб'єктність. Вони здійснюються завжди в межах відносних правовідносин, суб'єктами яких, згідно із загальним правилом, $є$ працівник і роботодавець. Вони $є$ активними за змістом, оскільки працівник вправі вимагати не тільки утримання роботодавця від будь-яких дій, що порушують його права, а й активних дій, спрямованих на реалізацію й захист цих прав. Метод правової рівності сторін (працівника і роботодавця) не застосовується в процесі реалізації трудових прав працівників.

Водночас носіями особистих немайнових прав, не пов'язаних із майновими, які охороняються цивільним правом, $\epsilon$ всі фізичні особи з народження. Зазначені права здійснюються завжди в межах абсолютного правовідношення, суб'єктом якого є правомочна особа, з одного боку, i невизначене коло осіб, з іншого боку. Вони мають пасивний зміст, оскільки правомочна особа вправі вимагати від усіх утримання від будь-яких дій, що порушують iі права. У процесі реалізашіі особистих немайнових прав застосовується метод юридичної рівності сторін.

Не всі вчені-трудовики підтримують ідею особистих немайнових трудових прав. Так, С.В. Венедіктов вважає, що застосування поняття «особисті немайнові права» в трудовому праві $€$ недопустимим, оскільки посягає на суверенітет галузі, шо майже сто років тому відокремилася від цивільного права. Особисті немайнові права $\epsilon$ абсолютними, тому розгляд їх через призму трудових відносин учений вбачає неможливим, оскільки не лише роботодавець, а й будь-який інший суб'єкт права зобов'язаний не порушувати особисті немайнові права особи-працівника. Крім того, за порушення особистих немайнових прав особа притягується до відповідальності в межах цивільного законодавства [14, с. 14].

Не можна погодитися з висновком автора про те, що особисті немайнові права є завжди абсолютними. Що стосується права на інформацію, яке реалізується в індивідуальних і колективних трудових правовідносинах, то воно $€$ не абсолютним, а відносним. Застосування поняття «особисті немайнові права» зовсім не посягає на суверенітет галузі, про що пише С.В. Венедіктов. Ідеться про необхідність розробки галузевого механізму забезпечення зазначених прав трудоправовими засобами, шо ніяким чином не стосується «суверенітету галузі».

Таким чином, право на інформацію сторін трудового договору можна визначити як гарантовану державою можливість вільного одержання, ви- 
користання, поширення, зберігання й захисту інформації, необхідної працівнику й роботодавцю для реалізації індивідуальних і колективних трудових прав, свобод і законних інтересів.

Класифікацію права на інформацію сторін трудового договору пропонується здійснювати за такими критеріями: за типом інформації, за суб'єктами, за режимом доступу (право на відкриту інформацію та право на інформацію з обмеженим доступом), за способом правового регулювання, за ознаками діяльності (існування) суб’єкта.

За своєю юридичною природою право на інформацію сторін трудового договору як суб'єктивне трудове право $є$ основним трудовим правом, індивідуальним трудовим правом, регулятивним трудовим правом, шо включає. як право на свої діï, так і право на чужі дії (право-домагання), особистим немайновим трудовим правом.

\section{Література}

1. Чанишев P.I. Право на інфформацію за трудовим законодавством України : дис. ... канд. юрид. наук : спец. 12.00.05 «Трудове право; право соціального забезпечення» / Р.І. Чанишев. - K., 2012. - $215 \mathrm{c}$.

2. Теория государства и права : โучебник для вузов / / под ред. проф. В.М. Корельского и проф. В.Д. Перевалова. - 2-е изд., изм. и доп. - М. : Издательская группа НОРМА - ИНФ. PA-M, 2002. - $616 \mathrm{c}$.

3. Рабінович П.М. Основи загальної теорії права та держави : 〈навчальний посібник」/ П.М. Рабінович. - внд. 5-те, зі змін. - К. : Атіка, 2001. - $176 \mathrm{c.}$

4. Марущак A.I. Інформаційне право України : ГпідручникГ / A.I. Марущак. - K. : Дакор. 2011. - 456 c

5. Елисейкнн П.Ф. О понятин н месте охраннтельных отношений в механнзме правового регулирования / П.Ф. Елисейкин // Кридические гарантии применения права и режим социалистнческой законности. - 1975. - Вып. 1. - С. 17-20; Крашенинников Е.А. Право на защиту / Е.А. Крашенинников // Методопогические вопросы теории правоотношений : тезисы IV областной научно-практической конференции молодых ученых и специалистов (5-8 февраля 1986 г.) / отв. нсполн. Е.А. Крашенннннков ; Яросл. гос. ун-т. - Ярославль : ЯрГУ, 1986. - С. 20-22: Крашенинников Е.А. Структура субъективного права и права на зашнту / Е.А. Крашенинников / / Проблемы зашнты суб́ъективных гражданских прав и гражданское судопроизводство. - 1979. - Вып. 4. - С. 17-19.

6. Андріїв В.М. Система трудових прав працівників та механізм їх забезпечення : автореф. днс. ... докт. юрнд. наук : спец. 12.00 .05 «Трудое право; право соціального забезпечення» / В.М. Андріїв ; Нац. ун-т «Одес. юрид. акад.». - О., 2012. - 40 с.

7. Краснов Є.В. Основні трудові права: міжнародні стандарти і законодавство Українн : авто. реф. дис. ... канд. юрид. наук : спец. 12.00 .05 «Трудове право: право соціа.льного забезпечення» / Є.В. Краснов ; Одеська національна юридична академія. - О., 2008. - 20 с.

8. Чанншева Г.Т. Колективні відносини у сфері праці: теоретнчні та практичні проблеми право. всго регулювання : автореф. дис. ... докт. юрид. наук : слец. 12.00.05 «Трудове право: право соціального забезпечення» / Г.І. Чанишева ; Одеська національна юрндична академія. - X., 2002. $-38 \mathrm{c}$.

9. Бару М.И. Охрана трудовой чести по советскому законодательству / М.И. Бару. - М. : К)ридическая литература, 1966. - 130 c.

10. Гинцбург Л.Я. Социалистическое трудовое правоотношение / Л.Я. Гинцбург. - М. : Наука. 1977. $-310 \mathrm{c}$

11. Трудовое право России : |учебник для бакалавров] / поп общ. ред. Е.Б. Хохлова, В.А. Са фонова. - 4.е изд., перераб. и доп. - М. : Издательство К райт, 2012. - 673 с. 
12. Лагутіна І.В. Особисті немайнові трудсві права працівників у системі трудових прав : |монографіяl / 1.В. Лагутіна. - О. : Фенікс, 2014. - 428 c.

13. Маленна М.Н. Понятне н внды нематернальных благ как объектов личных ненмущественных прав / М.Н. Маленна / / Государство и право. - 2014. - № 7. - С. 40-47.

14. Венедіктов С.В. Концептуальна засади правового регулювання трудових відносин в Утраїні : автореф. дис. ... докт. юрид. наук : спец. 12.00 .05 «Трудове право: право соціального забезпечення» / С.В. Венедіктов. - К., 2012. - 38 с.

\section{A н от а ція}

Чажишева $\Gamma . I .$, Чажuшев P. I. Поняття, види та юридична природа права на інформацію сторін трудового договору. - Стаття.

У статті визначаються поняття म̆ види права на інформацію сторін трудового договору. Аналізусться юридична природа зазначеного права як суб'сктивного трудового права. Право на інформацію сторін трудового договору характернзується як основне трудове право, індивідуальне трудове право, регулятивне трудове право, особисте немайнове трудове право.

Kлияові слова: інформація, право на інформацію, працівник, роботодавець.

\section{Аннот а ци}

Чажышева Г. И., Чажышев Р. И. Понятие, виды и юридическая природа права на информацию сторон трудового договора. - Статья.

В статье определяются понятие и виды права на информацию сторон трудового договора. Анализируется юридическая природа указанного права как субъективного трудового права. Право на информацию сторон трудового договора характеризуется как основное трудовое право, индивидуальное трудовое право, регулятивное трудовое право, личное ненмущественное трудовое право.

Kanневье слова: информация, право на информацию, работник, работодатель.

\section{S u in in a r y}

Chanysheva G. I., Chanysheo $R$. I. The definition and types and legal nature of the right to information of the parties of the labor contract. - Article.

The article defines the concept and the types of the right to information of the parties of the labor contract. Analyzes the legal nature of this right as a subjective labor law. The right to information of the parties of the employment contract is characterized as a basic labor rights, individual labor law, regulatory labor law, moral labor law.

Key worts: information, right for information, employee, employer. 